\title{
Humanities Grant to Rare Book Library Will Support Six-Year Bibliographic Project
}

John Carter Brown Library of BROwN UNIVERSITY, one of the world's largest collections of books and maps relating to the first three centuries of American history, has received a major research grant from the National Endowment for the Humanities (NEH)to produce a chronological guide to writings on the Americas published in Europe before 1801 .

The $\$ 232,000$ award, the second largest grant received by Brown University in recent years for a project in the humanities, will be supplemented by an in-kind university contribution of some $\$ 59,000$ and an additional $\$ 66,000$ provided by the Readex Microprint Corporation of New York. which will publish and market the eight-volume bibliography when it is completed. The Readex firm has been assisting the library since 1968 to assemble materials for the project in preliminary form.

Expected to include 45,000 separate listings of books or other printed materials, the proposed chronological guide is designed, said John Carter Brown Librarian Thomas R. Adams, to help answer a complex of questions that faces scholars attempting to study the early development of the American continents: that is, what did Europeans know about the New World, when did they know it, how did they leam it, and what effect did the new information have on them?

Since the expansion of knowledge in Western Europe is inextricably linked to the spread of printing, it is vital, Adams explained, for scholars to know what information about America was published in Europe and when. To date, students of New World history have had to rely largely on an unwieldy and now out-of-date twenty-ninevolume bibliography called the Dictionary of Books Relating to America.

Begun in the middle of the nineteenth century by a bibliographer named Joseph Sabin, the work was finished by others in 1936 . It was alphabetically, rather than chronologically, arranged, the JCB librarian notes, thus obscuring the inter- relationships between works printed during a given period.

A more significant reason for updating the Sabin reference work lies within the John Carter Brown Library itself. Over the years, the library has acquired enough important European imprints from the period 1493-1800, not listed in Sabin, to more than double the number of entries appropriate to a revised version of the list. The new chronological guide will also aim for comprehensiveness, listing relevant materials held in other collections as well

The NEH funding, which will cover the first three years of what Adams expects will be a sixyear undertaking, will pay for the addition of a special bibliographic team to the JCB staff, charged wth responsibility for preparing the new list for publication and completing a computerized index to accompany it.

Already at work on the massive project is the guide's editor, John Alden. Recently named keeper emeritus of rare books at the Boston Public Library, where he had supervised the rare book collections for some twenty years. Alden is widely known for his contributions to the fields of librarianship and historical bibliography. The author of monographs and hooks, including a bibliography of pre-1800 Rhode Island imprints, Alden has held posts on the staffs of the British Museum, the Library of Congress, and the Houghton Library at Harvard and has served as a library consultant to many other institutions.

"In the sense that scholars using the chronological guide will find many new texts they weren't aware of before, this project will raise more questions than it answers," Adams said. "But working with original sources is a dynamic process in which new information is continually developing, and I am pleased that the NEH grant will allow us to use the unique resources of the John Carter Brown Library to take the leadership role in that process."

\section{Ramapo College Dedicates New Library}

On November 17, Ramapo College, Mahwah, New Jersey, dedicated its new $\$ 4.2$ million library, marking the completion of the new state college's initial building program. Ground was broken for the four-year liberal arts college on November 17, 1970.

The official dedication ceremonies featured re- marks by the 1962 Nobel Laureate James Dewey Watson, who received the Nobel Prize for Medicine for his work in unraveling the molecular structure of DNA-the key to cell reproduction. Watson currently serves as director of the Cold Spring Harbor Laboratory.

Edward Hollander, New Jersey chancellor of 
higher education; Ramapo College President George T. Potter; and Wilson Sterling Dillon, director of symposia and seminary at the Smithsonian Institution, also were among the keynote speakers.

The Ramapo College Library ceremonies spanned four days, November 15-18, and included displays by members of the Ramapo faculty, staff, and students, Special exhihits in the library included "Stage and Screen," highlighting the artistic achievements of Pulitzer Prize winning playwright Sidney Kingsley and his wife, actress Madge Evans, of Mahwah; and "Political Triumphs and Tragedies," an audiovisual display of major political figures, with actual voice tapes, campaign memorabilia, and the well-known Quackenhush Collection of Historical Sound Recordings of $78 \mathrm{rpm}$ dises.

On November 16, Ramapo College hosted an all-day conference on the media for area high school students with Dave Marash, CBS News
Coanchorman, as the keynote speaker. Watson gave a public lecture on "Science and Society," followed by an open house and public tour of the new college Library facilities.

The new Ramapo College Library contains 62,000 square feet and cost $\$ 4,200,000$. It was designed by Mahony and Zvosec/Kenneth Demay of Princeton and Watertown, Massachusetts. The hook collection contains 120,000 volumes, including daily editions of the New York Times since 1851. In addition, the library maintains a large number of slides, films, records, multimedia kits, and a collection of topographic maps of New Jersey and neighboring states. Special facilities for disabled and visually impaired students are also included in the barrier-free building, including a Braille typewriter and large-print hooks. Open seven days a week, the Ramapo College Library serves the academic, cultural, and intellectual needs of the entire Ramapo community.

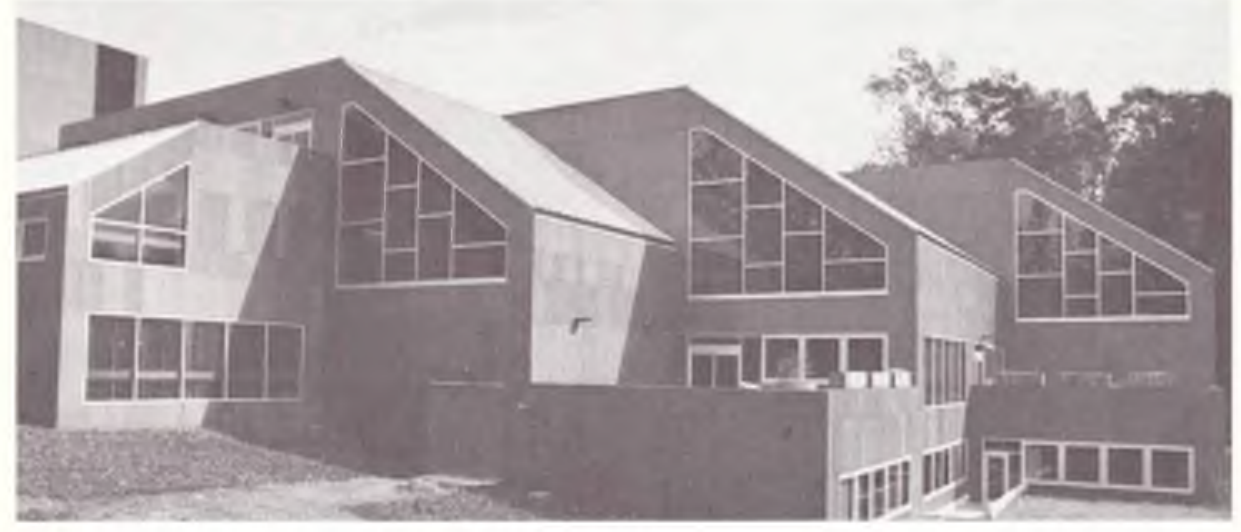

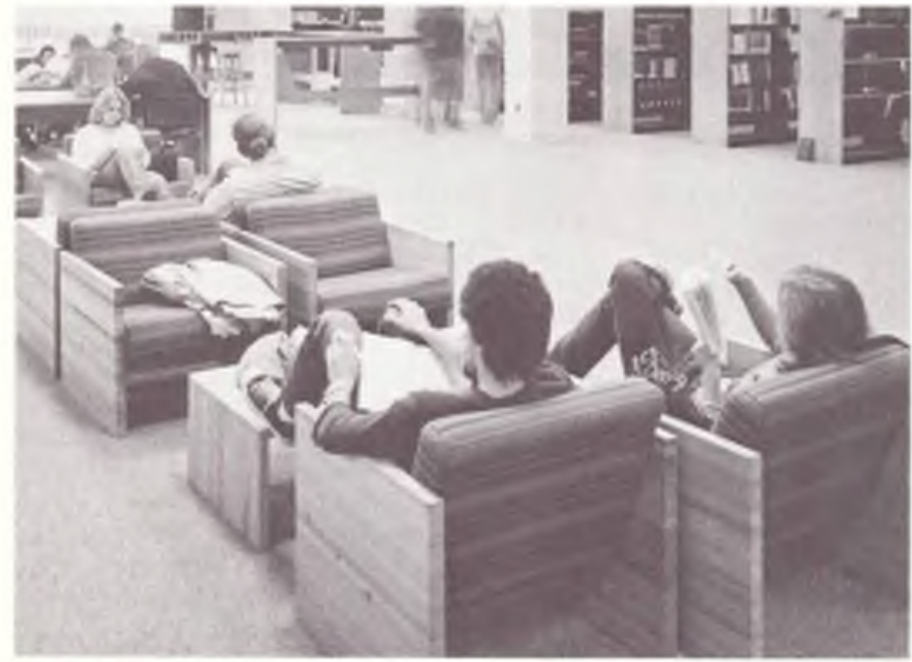

Exterior and interior views of new Ramapo College Library. 